\author{
A. R. Kobetiak, PhD in Philosophy, doctoral student \\ Ivan Franko Zhytomyr State University, Zhytomyr, Ukraine \\ ORCID: 0000-0002-0457-922X \\ e-mail: kobetiak@meta.ua
}

\title{
ECCLESIOLOGICAL CONDITIONALITY OF THE AUTOCEPHALOUS SYSTEM OF THE UNIVERSAL ORTHODOXY
}

\begin{abstract}
The article deals with one of the fundamental problems of the whole corps of the church law - autocephalous principle of the existence of the church. This problem drives the researchers' attention to the very essence of the existence of orthodoxy in general. The preaching of Christ and the Gospel leave no direct pointers of the internal organization of the church. The apostles make only the subtle hints to the administrative arrangement of the church in general. Their mission preaching and spreading the faith to all nations, however, they did not envisage any other administrative system than autocephaly. Church dogmas and canons, which regulate all aspects of the life of the Church, were formed during the heyday of Christianity in the Byzantine Empire. However, the significant politicization and dependence of the church on imperial power led to the proclamation of a number of canons that contradicted the original nature of the church. This also applies to autocephaly. Under the pressure of the state authorities, the primacy of honor together with ancient Rome is shared by the capital's Constantinople chair. The theory of the "Five Patriarchates" is being formed, which are called to rule the world Orthodoxy. During the Ecumenical Councils, autocephaly was transformed from a basic and natural state of the Church existence into a certain privilege and a subject of political bargaining in the international arena.

Despite the long process of forming the canonical and legal corps of Orthodoxy, there is no clear regulation of the procedure for proclaiming a new autocephalous church today. This led to significant misunderstandings and the termination of Eucharistic communion by a number of Local Churches after granting autocephalous status to the Ukrainian Church. Theological disputes over the very procedure of signing the Tomos still take place today.

Besides theoretical justification, the internal church structure also has a practical value for the process of bestowing autocephaly on the new national Local Churches. This is relevant due to the struggle of a number of modern countries for the church independence and the Ecumenical recognition. Starting since the Byzantine Empire times, the state power has constantly imposed its own church management principle and methods, which often was going against traditions and canonical norms. Orthodox ecclesiology offers its own approach to church-administrative management. It is proved that merely the autocephalous system is the only acceptable option of the existence of the Universal Orthodoxy.

Keywords: autocephaly, ecclesiology, church, orthodoxy, metropolitanate, cathedra, administrative structure.
\end{abstract}

The Orthodox church tradition, which was founded by the apostles and acquired its defined features during the Ecumenical Councils, has been forming over two thousand years. However, in modern realities this process causes the need to rethink it. The Church, as a unique living divine-human organism, is a dynamical, as it changes along with human generations. According to the Orthodox Catechism, God is eternal and unalterable. The special grace of the Holy Spirit fills the Church. In the Epistle to the Ephesians it is stated about the Church: "And God placed all things under His feet and appointed Him to be head over everything for the Church, which is His body, the fullness of Him who fills everything in every way!" (Ephesians 1:2223). But another component of the Church is a man, and we are talking about both the living and the dead, as according to the orthodox doctrine the soul is immortal. In everyday meaning, most people understand the term "church" as a place of worship or an entire religious organization, with which they identify themselves. For example, someone is a parishioner of a Baptist church, or an Orthodox one, or is a Christian in general, that is, we are talking about confessions and denominations.

The relevance of the study is to highlight an important problem of the church structure. The autocephalous status and the possibility of acquiring it have always been the cornerstone of theological debates. The apostles, in founding separate communities and churches did not know or foresee any other church administration and structure apart than an autocephaly. Each community, led by a bishop, was already self-sufficient by its essence. However, already in the II-III centuries the church borrows the administrative division and management of the Roman Empire. The church structure was finally formed during the rise of the Byzantine Empire, when the emperor was, in fact, the head of the church. The empire did not just conquer the church, it blurred it into itself. No doubt, Christianity received significant privileges and powerful potential for quality development and internal filling. This is the heyday of theology and church culture. But the church had to forget about its independence in the political aspect. The autocephalous principle of the church structure is transformed from a basic imperative into a privileged state. "The golden age" of canonical creativity during the Ecumenical Councils practically ignored the problem of forming any new autocephalous church. The mechanism of such a process itself has not been developed. This led to significant upheavals of the Universal Orthodoxy in the future. Today there are 15 positions in the general diptych. Most of the Local Churches gained autocephalous status after a long struggle for their own independence. In many cases, it was accompanied by the self-proclamation of a new church administrative unit and the period of termination of Eucharistic communion with the mother church, in particular with the Russian and Bulgarian Orthodox Churches. The bestowing the Tomos on the Ukrainian Church has once again intensified discussions on the possibility of acquiring autocephalous status and the procedure for recognizing a new administrative unit in the structure of the Universal Orthodoxy. Thus, Orthodoxy is leading itself into a dead end. On the one hand, in the absence of a mechanism for acquiring the autocephalous status of Orthodoxy, new Local Churches appear periodically, on the other hand - according to the Orthodox ecclesiology, this status follows from the very nature of the church and its essence. The struggle for power within the church, even for spiritual one, runs counter to Christ's preaching of love and equality.

The issue of autocephaly is not only important and interesting for experts, but also for the general public of those who are interested in religious issues, in particular in Ukraine. The signing of the Tomos for the Ukrainian Church caused a significant resonance in the world, and as for today only a part of the Local Churches have recognized this act as a legitimate one. Apart from that, it requires an urgent solution due to the sharp requests of modern society for the independence of individual national churches.

The aim of this article is to try to bring more clear awareness what it means to be a Church and what management structure is inherent to it. The autocephalous system of the Universal Orthodoxy structure is inseparably linked with the apostolic teaching and the ecclesiological tradition of the ancient Eastern churches. The very nature of the church, according to the Orthodox ecclesiology, must be independent of any attempts to usurp the church power. 
Therefore, the study focuses on the very phenomenon of the Church in its historical retrospective.

The state of scientific development of the chosen topic should be characterized in two ways. On the one hand, there are hundreds of speeches, public statements and official letters from theologians and hierarchs of various Local Churches on autocephalous issues. The bursts of such activity coincide with the proclamation of another national autocephaly in the XX century. Most of these documents and statements have a polemical nature. On the other hand, the scientific justification of autocephalous issues was significantly intensified again in connection with the signing of the Tomos for the Ukrainian Church.

The works of the following Ukrainian church historians and canonists are valuable for this scientific research: I. Vlasovsky, O. Kyrydon, O. Lototsky, Y. Mulyk-Lutsyk and others, who repeatedly drew attention to the process of emergence of the institution of autocephaly. Special mention should be made of scholars who studied the period of formation of the canonical code of the Orthodox Church in the period of early Christianity and the Ecumenical Councils. In particular, we will mention such worldwide known researchers of church history: V. Asmus, D. Bingem, A. fon Garnak, J. Hofmann, J. Zizioulas, I. Isichenko, J. Robertson, A. Kartashev, Eusebius of Caesarea, N. Milash, E. Smirnov, S. Smirnov, K. Skurat, F. Uspensky and others. The works of the above-mentioned scholars reveal the main periods of formation and objective-situational conditionality of the autocephalous principle of the church's existence, including in terms of Orthodox ecclesiology.

It is necessary to note separately some modern dissertation researches of V. Butynsky, M. Gergelyuk, A. Didkivsky which reveal process and essence of autocephalous formation of orthodox churches. It is important that a qualitative analysis of autocephalous issues in the context of the Ukrainian church issue can be traced in the modern national scholars studies. The scientific work of the famous theologian Archimandrite Cyril (Govorun) is relevant. In particular, his monograph on ecclesiology, where much attention is paid to the problem of autocephaly and its ecclesiological conditionality. A fundamental study is a fourvolume book by $\mathrm{V}$. Bolotov on the history of the formation of the ancient Church, which reveals the growth of the parish network and the internal system of Orthodoxy of the early and councils' periods. In general, the studies of the following leading researchers were useful for this research: A. Aristova, L. Vladychenko, D. Gorevy, O. Gorkusha, V. Yelensky, S. Zdioruk, A. Kolodny, O. Sagan, P. Saukh, A. Smirnov, L. Filipovych, Y. Chornomorets, A. Yurash, $P$. Yarotsky and others, who subject the processes of autocephaly in Orthodox canon studies to the critical religious and philosophical analysis.

Despite the significant scientific and theological aspect of the relevance of the stated issue, today there are a number of unresolved issues regarding the harmonization of the issue of the autocephalous structure of the Ecumenical Church with the norms of canon law and Orthodox ecclesiology. In addition, scientific studies do not show a clear connection between the ecclesiological model of the ideal church of Christ and the modern administrative structure of the church life. The presence of a number of littlestudied scientific problems regarding the autocephalous arrangement of the Ecumenical Church significantly actualizes the selected topic.

The term "church" comes from the Greek word

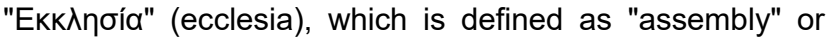
"convocation". Thus, the fundamental meaning of the church is not the building but people. This is confirmed by the words of Holy Scripture: "Greet Priscilla and Aquila, my fellow workers in Christ Jesus, who risked their necks for my life, to whom not only I give thanks but all the churches of the Gentiles give thanks as well, greet also the church that meets at their house". (Romans 16:3-4). Paul mentions the church in their house - not a church building, but a community of believers. Thus, the church (ecclesia) is a voluntary observable assembly of believers, who are organized into a separate parish, which in fact is a completely autonomous entity. Whoever is not a member of the ecclesia, is not a parishioner of a particular parish [1, p. 13].

The basic rules and standards of life in Orthodoxy were formed during the Ecumenical Councils. The understanding of the essence of the Church has been transformed over centuries of history, while the basic teaching has remained unchanged. Therefore, ecclesiology as the science about the Church, today is one of the fundamental theological disciplines. The secularized society of the postmodern era needs a thorough understanding of the essence, role and mission of the Church in human life. The problem of the autocephalous status of an individual Local Church is inseparably linked with the science of the church by and large. The church, like any other social institution, must have its own earthly form of management and administrative system. It is clear that the Church is a divine-human organism, which is guided directly by the Lord, because the Orthodox doctrine clearly states that the head of the Church is Christ [9, p. 137]. But in the God - man vertical everything is locked on the earthly church organization as one of the important social institutions. Therefore, the earthly dimension of the church institution requires careful study in terms of church-administrative management. In the XXI century the church theme remains particularly relevant. First of all, this is due to the fact that among other social institutions in many developed countries, and in Ukraine in particular, the church is trusted by the largest number of citizens [10]. In addition, building of the civil society, that is being debating nowadays by the world's leading thinkers, is also impossible without the religious factor [6, p. 123].

The administrative structure of the Roman Empire, already formed at that time, was the basis for the territorial organization of the early church. Even back in the apostolic age, the church began to focus on some cooperation, and sometimes on direct dependence on secular authority. Already at the time of the councils' period it was reflected in the canons and official decrees. For example, the $17^{\text {th }}$ canon of the Council of Chalcedon unambiguously and clearly binds the borders of the eparchy to the state administrative division: "In case the imperial government has founded a new city, the division of parishes should be made according to administrative and land zoning" [3, p. 46]. The 38th rule of the Fifth and Sixth Councils sounds in the similar way of saying. These official canonical norms have been of great importance in the future for the formation of the structure of the Ecumenical Church. It was due to these canons that new autocephalous churches became possible, which did not exist and could not exist in the era of the Ecumenical Councils, therefore, they are not approved by the highest Ecumenical authority of church administration [8, p. 128].

In the Ante-Nicene period, appears the concept of "кат

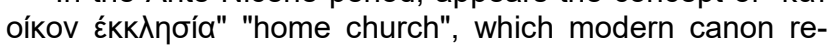
searchers has no unambiguous definition for. Based on the opinion of an authoritative theologian J. Zizioulas, the author believes that the home church goes beyond the purely family relations. More likely, the adjective indicates the location rather than the social nature of the church gathering. After all, in the early period of the church there was a rule of "one Church - one Eucharist - one city", meaning that in the one single city there was the only sole "home church" [4, p. 252]. No testimony from church historians 
has been found by nowadays that would indicate any problems with the formation of "home churches" into a single church. At the same time, this very concept is rapidly disappearing from the historical arena.

Already at the First and Second Ecumenical Councils the concept of "metropolitanate" has finally been affirmed. This is the next stage in the formation of the churchadministrative system on a territorial basis. Nicodemus Milash - the hierarch and the famous canonist of that time - notes that the metropolitanate, in the Councils' era, corresponded to the concept of the Local Church, and was independent [12, p. 70]. This is confirmed by the authoritative comments of Aristine, Zonara, Valsamon and the Slavic Kormchaia Book. In the metropolitanate, as an independent unit of church administration, the $34^{\text {th }}$ apostolic rule is best traced, which testifies to the precedency and independence of the Primate among other bishops [13, p. 168].

In our opinion, it's important to highlight the practice of approval of the rules and resolutions of the Councils by the imperial signature and seal. On the one hand, it pointed to the incompleteness of independence of the decisions of the church fathers without the consent and resolution of the state authorities. Meaning that the church was entirely dependent on the will of the head of the Byzantine Empire. But on the other hand - it provided the state importance to the church rules. After the Council, they became mandatory, as they were published under the imperial seal $[15$, p. 202]. During the reign of Justinian the Great, imperial power in the question of the autocephalous system of the church has become absolute. Thus, by the imperial decree, the autocephalous status was in fact granted to New Justinian - the hometown of Basileus, with the subordination of several neighboring eparchies [15, p. 201]. The Fifth Ecumenical Council, held during the reign of Justinian, showed a tolerant attitude to Christological issues, but did not react in any way to such a state decree [19, p. 163]. However, if there was such an affirmative decision (back then an objection was not an option, as the emperor could repress the participants of the council) of state regulation, then in the following times it could considerably simplify the formation of new autocephalies according to the state regulation of this question. However, the Ecumenical Councils practically ignored the very mechanism of forming a new independent church. At that time, it was purely unthinkable event to happen outside the empire and without personal regulation of the matter by the emperor.

The lack of a regulated mechanism for the proclamation of a new independent church unit has led to the formation of different traditions and practices among the representatives of the Local Churches in the issue of granting the autocephalous status. Step by step, two courses of ecclesiological apprehension of the essence and nature of the autocephalous structure of the church at the local, regional and universal levels has been formed. The first one focuses on the Greek-speaking world and the theological heritage of the Byzantine Empire. This course is supported by the ancient patriarchates and some newly proclaimed Local Churches that have Greek heritage and traditions, such as the Churches of Greece and Cyprus. This approach implies the existence of a certain "gathering point" of independent Local Churches, which is represented by the Ecumenical Patriarchate as the mother-church of other autocephalous churches. The formation of a new independent church depends on the Patriarchate of Constantinople. And an estrangement from it means an estrangement from worldwide Orthodoxy [18, p. 213].

The second, Slavic approach, assumes the existence of Local Churches as a confederation of completely autonomous entities. There is no dependence between the Local
Churches. The supremacy of authority is completely denied, and even the honor of the Ecumenical Patriarchate is denied - at the unofficial level [11]. According to this tradition, the mother-church has the solo prerogative not to / grant the autocephalous status to the daughter-church. Other Local Churches must recognize the newly proclaimed Local Church post-factum. No common denominator in the theological debates of the representatives of the various Local Churches is expected. This was proven by the Pan-Orthodox Council of Crete, which was scheduled for 2016. Four Local Churches did not come to this meeting due to certain political motives. One of the main issues on which no agreement has been reached is the document "Autocephaly and ways of its proclamation". If a specific mechanism for bestowing the autocephalous status on a certain national church was approved, as was expected from the above stated document, then a number of churches, for example (as of 2016) Ukrainian, Montenegrin, Macedonian churches would immediately begin the process of independence from kyriarchal (supreme, mother) churches.

Referring to the history of the formation of the first autocephalous churches, which were formed as a result of the unification of several eparchies (bishoprics), we can see, that all of them has been formed according to the $34^{\text {th }}$ Apostolic Rule which states that the bishops of a particular territory need to know the first one among themselves, that is the Primate. Such were the provincial churches of Lycia, Egypt, Pontus, and Bithynia [2, p. 40]. These were the first Local Churches in the theological-ecclesiological meaning, that is, they were located "locally" in a particular region. Over time, the term "local" has been identifying with the autocephalous, i.e. independent church. This is a church unit that is completely self-governing, located in a specific area where a certain population live, and an important condition is its unity in the doctrine and the Eucharist with other Orthodox churches over the world [7, p. 91]. Over the course of history, the first metropolitanates and archdioceses were formed in the capital cities, for example, Rome, Antioch, Alexandria, Cyprus. Later, they were transformed into the first patriarchates, which have the highest church authority till nowadays.

The ecclesiological understanding of the locality and, consequently, of the autocephalous structure of the church is inseparably connected with the Eucharist. Where this basic Christians sacrament is celebrated, there is a church. On the one hand, the Eucharist is performed in a particular place at a certain time, but on the other, because of its mysticism and a universal nature, - it unites absolutely all members of the church, including the dead ones. Hence, the autocephalous church unit, which is located in a certain area, and has the fullness of the Eucharistic communion with other churches, includes absolutely all members of the Orthodox Church living in that region. All Orthodox, regardless of profession, gender, age, language, are partakers of the Eucharist, which is celebrated in this place. This indicates that there can be only one Local Church in one separate territory, which clearly corresponds to the 34th Apostolic Rule. After all, the church, in its earthly dimension, is always tied to a specific location, such as the church of Cyprus or Corinth [17, p. 201].

The basic concepts of the modern canonical structure of the church, such as "metropolitanate", "eparchy", "patriarchy", "autocephaly" do not have a specific ecclesiological meaning. In fact, they are not even included in the scope of ecclesiology. Ecclesiology, as a theological science, answers the question: what is the church, what is its essence. The above-mentioned concepts are categories of the administrative system of church life that came to the church over time. However, one way or another, the administrative 
division has been inherent in the church since apostolic times. This became especially evident during the times of Byzantine Empire. As for the concept of "autocephaly", in administrative terms it is the highest degree of division of the Ecumenical Church into independent, i.e. selfgoverning parts on a territorial, national and state basis. From the ecclesiological point of view, the autocephalous principle should be reduced to independence, which corresponds to the ancient custom, which is the norm of the canon law: one territory - one bishop, and thus - one church. Therefore, the $34^{\text {th }}$ Apostolic Rule commands the bishops of one territory (country) to know their first hierarch, whom they themselves must deliver to the capital's chair [2, p. 47]. Thus, the concept of autocephaly, although is not included in the basic categories of ecclesiology as a science, but directly follows from the ecclesiological principle of one territory - one bishop - one Eucharist.

Understanding autocephaly as an external manifestation of the church leads us to the certain structures and layers that have been established in the church over time. Mostly they were institutionalized into the church consciousness during the Ecumenical Councils, when the state authorities finally reaffirmed their own leadership of the main church processes. Ecclesiology is the science of the church in general, but the emphasis is on the internal structure of the church. The main question of this theological discipline is what is the essence of the church. And the answer is clear. The Church is first and foremost the Eucharist and the people. Therefore, it is easy to combine the ecclesiological understanding of the church with the modern autocephalous system. Where there are believers united by a common faith and idea, and where the Eucharist is celebrated, especially if the sacrament is presided over by a bishop, there is the church. In its essence, it is selfsufficient, and therefore independent. After all, the ideals of the early Christian period have left us with no evidence of a certain hierarchy of one community against another.

Thus, the division of spiritual power into separate administrative points would lead to the complete decentralization of the power in the church, that, in fact would correspond to the apostolic times. This would cause a significant resonance, because today a number of churches seek their own independence and world recognition. A statement should be recalled in support of this view, that the excessive legal centralization of church power, as such that does not correspond to the Orthodox tradition, was condemned by episcopate of Local churches at the Inter-Orthodox meeting in 1963 on the occasion of the celebration of the 1000th anniversary of the Great Lavra on Mount Athos [15, p. 204].

It should be noted that today Orthodoxy, same like the other Christian churches, has overgrown with significant layers and completely immersed into economic issues. Therefore, the issue of church authority and management of the church as an earthly institution today occupies an absolute part of the attention of hierarchs and leading theologians. Instead, in early Christianity, management was handled exclusively by deacons - the lowest echelon in the hierarchy. And for the Bishops, as the most charismatic members of the church community, it was a matter of teaching and preaching the truth of God. Now the situation has changed. Bishops only administer, and deacons, priests, and especially the laity testify to the verity and truth. Therefore, today's silence of the hierarchy about the most painful problems of the church (simony, despotism, sodomy, all-corruption, immoral way of life, excessive enrichment of certain hierarchs) and society in general is a consequence of global breakdowns somewhere in the depths of our ecclesiological consciousness [14].
As in the times of the Byzantine Empire, so in the $\mathrm{XXI}$ century there is a process of adaptation of the church system in the conditions of new state organizations. On the one hand it can be opposed to the government, and on the other hand - to submit to and be part (one of the institutions) of state regulation of public life $[8, p .5]$. But the Byzantine Empire, as well as later the Russian Empire, saw the church institution as a powerful support and ideological affirmation of state power, and most importantly - its sacralization. The consecration of the "anointed of God" by the higher hierarchy could add mystical significance to the power structures. The emperor was considered as a God's messenger for the salvation of the people. Therefore, although the state used the church for its own purposes to put pressure on the people, it also supported it as one of the key determinants of power strengthening.

In today's globalized society, the situation has not changed in the sense that the state continues to flirt with the church, using it for its own benefit. However, today the church does not have such support and state protection as a thousand years ago. Instead, the Orthodox hierarchy is constantly involved in certain political conflicts, which are successfully used by political opponents. In turn, this leads to the loosening of society, loss of its confidence in the hierarchy, and because of this in the church in general, to the problem of religious self-identification of ordinary citizens. The most painful knot of problems for ordinary people is the issue of the church elite supporting the state power and not the citizens, as it happened after the elections in Belarus. The Church, which is supposed to be with people, which basically, in its ecclesiological meaning, is the people, would rather support the government that has been lobbying the interests of a particular denomination for decades [14].

At the same time, for any church of the Byzantine tradition, the support of the authorities is the normalcy of the lifestyle. In a Belarusian or similar situation, to support the people is to make a leap into nowhere, into the unknown. We can say that this goes against nature itself and church ecclesiology, which have been building for centuries the idea of the divine origin of power and its comprehensive sanctification. In modern realities, the situation is not much different from the Byzantine "symphony", when the church politically and economically depends on the decision of the state. It is not surprising, therefore, that during the Soviet period the church was able to enter into a "symphony" relationship even with an openly atheistic regime.

In summary, we note that despite the long history of the formation of the Orthodox tradition and doctrine, which is expressed in canon law, there is no clear regulation of the procedure for proclaiming a new autocephalous church in Orthodoxy. The Church has not developed a unified approach to the procedure for proclaiming a new autocephalous church, despite the fact that from time to time (especially at the turn of the XIX - XX centuries) new national churches have appeared. The "golden age" of theology and canonical dogmatic creativity that held place in the Middle Ages did not consider autocephalous issues as a priority area of the church-administrative system. The rules of the Ecumenical Councils state the existence of already formed historically ancient patriarchates, their status is consolidated, and the powers of the capital's Constantinople chair along with Ancient Rome are singled out. Orthodox ecclesiology has its own approach to the process of systematization of the structure of the Ecumenical Church. First of all, this is due to the very understanding of the Church as a living divine-human organism that is not sustainable. The church is always changing, because generations of people are changing. That is, the Church is first of 
all a gathering of people. On the other hand, the Church is the Eucharist, where it is celebrated there is the Local Church, which includes representatives of all classes, professions and nationalities who live in a particular place and are Orthodox. Thus, the Church should have a pronounced local spirit, because the Eucharist is celebrated in a specific place at a certain time. And according to the 34th apostolic rule, there is one Primate, i.e. the leader of local communities, who can be at one place. Thus, according to the ecclesiological doctrine about the Church and its structure, the autocephalous system is indeed the basic principle of the existence of the Universal Orthodoxy.

\section{Список використаних джерел}

1. Болотов В. Лекции по истории древней церкви (в 4 т.). Т. 1 : Введение в церковную историю / В. Болотов. - СПб. : типография М. Меркушева, 1907. - 252 с.

2. Гергелюк М. Канонічні та екпезіологічні засади автокефального устрою церков у структурі Вселенського православ'я: історичний контекст : дис. канд. іст. наук / М. Гергелюк. - Чернівці, 2014. - 199 с.

3. Джерела канонічного права Православної церкви / пер. 3 грецької Я. Туркала. - Х., 1997. - Вип. 1. - 112 с.

4. Зізіулас Й. Буття як спілкування. Доспідження особистісності і Церкви / Й. Зізіулас. - К. : Дух і літера, 2005. - 276 с.

5. Книга правил Святых Апостол, Святых Соборов Вселенских и Поместных и Святых Отец. - М. : Изд-во святителя Льва, Папы Римского, 2010. -447 c.

6. Кобетяк А. Толерантизация и императив диалога в реалиях украинской конфессиональной жизни / А. Кобетяк // Веснік Гродзенскага дзяржаўнага ўніверсітэта імя Янкі Купалы. Серыя 1. Гісторыя і археалогія. Філасофрія. Паліталогія. - Гродно, 2014. - № 1 (166). - С. 120-126.

7. Лосский Н. Соборность-кафоличность и первенство в православной экклезиологии. Православное учение о Церкви / Н. Лосский. М., 2003. - С. 91 .

8. Лотоцький О.Г. Автокефалія. Нарис історії автокефальних церков : в 2 т. / О.Г. Лотоцький. - Варшава, 1935. - Т. 1: Засади автокефалії. - 207 с.

9. Николай Сербский, святитель. Вера святых. Катехизис Восточной Православной Церкви. - М. : Изд-во Никея. 2013 г. - 256 с.

10. Оцінка громадянами діяльності влади, рівень довіри до соціальних інститутів та політиків, електоральні орієнтації громадян (лютий 2020p. соціологія). - URL: http://razumkov.org.ua/napriamky/sotsiologichnidoslidzhennia/otsinka-gromadianamy-diialnosti-vlady-riven-doviry-dosotsialnykh-instytutiv-ta-politykiv-elektoralni-oriientatsii-gromadian-liutyi-2020r.

11. Позиция Московского Патриархата по вопросу о первенстве во Вселенской Церкви. Журнал № 157 Священного Синода РПЦ от 2526 декабря 2013 г. - URL: http://www.patriarchia.ru/db/text/3481089.html.

12. Правила Православной Церкви сь толкованіями Никодима, епископа Далматино-Истрійського : у 2 т. - СПб., 1911. (Репринт: Издание Свято-Троицкой Сергиевой Лавры, 1996 г.). - Т. 2. - 649 с.

13. Правила Св. Поместныхъ Соборов съ толкованіями. В 2 ч. Ч. 2. Правила первых шести Святых Поместныхъ Соборов. - СПб., 2001. $886 \mathrm{c.}$

14. Православная Церковь и протесты в Белоруссии-3. Комментарий архимандрита Кирилла Говоруна. 08.16.2020. - URL: https://reltoday.com/ news/pravoslavnaja-cerkov-i-protesty-v-belorussii-3.duUpyAeк.

15. Саган О. Вселенське православ'я: суть, історія, сучасний стан / О. Саган - К : Світ Знань, 2004 - 912 с.

16. СЛУЖІННЯ СОПРИЧАСТЮ: переосмислення зв'язку між першістю і соборністю. Заг. ред. архімандрита Кирила (Говоруна). - К. : ДУХ І ЛІТЕРА, 2020. - 220 c.

17. Цыпин В., протоиерей. Каноническое право / В. Цыпин. - М. Изд-во Сретенского монастыря, 2009. - 864 с.

18. Шишков А. Церковная автокефалия через призму теории суверенитета Карла Шмитта / А. Шишков // ГОСУДАРСТВО - РЕЛИГИЯ ЦЕРКОВЬ. - 2014. - № 3. - С. 197-224.

\section{А. Р. Кобетяк}

Житомирський державний університет імені Івана Франка, Житомир, Україна

ЕКЛЕЗІОЛОГІЧНА ЗУМОВЛЕНІСТЬ АВТОКЕФАЛЬНОГО УСТРОЮ ВСЕЛЕНСЬКОГО ПРАВОСЛАВ'Я

Розглядається одна з фундаментальних проблем цілого корпусу церковного права - автокефальний принцип існування церкви. Ця проблема заглиблює дослідницьку увагу до сутності існування православ'я загалом. Крім теоретичного обґрунтування, внутрішній церковний устрій має й практичне значення для процесу автокефалізації нових національних Помісних церков. Це є актуальним у зв'язку з боротьбою низки сучасних країн за церковну незалежність та Вселенське визнання. Державна влада, розпочинаючи з часів Візантійської імперії, постійно нав'язувала власний принцип та методи управління церквою, що часто йшло всупереч традиціям та канонічним нормам. Православна еклезіологія пропонує власний підхід щодо церковно-адміністративного управління. Доведено, що лище автокефальний лад є єдино прийнятним варіантом існування Вселенського православ'я.

Ключові слова: автокефалія, еклезіологія, церква, православ'я, митрополія, кафедра, адміністративний устрій.
19. Соколовський О.Л. Христологічний дискурс у період діяльності П'ятого Вселенського собору / О. Л. Соколовський // Гілея. - К., 2018. Вип. 135 (№ 8). - С. 170-175. 1: An Introduction to Church History. St. Petersburg: typography (in Russian].

2. historical context. The thesis for the degree of Candidate of Historical Sci(in Ukrainian].

3. Sources of canon law of the Orthodox Church. Translated from the

4. Turkal. Issue 1. X., 1997. P. 112 [in Ukrainian].

Zizioulas, J. Being as Communion: Studies in Personhood and the eo, Pope, 2010. P. 447 [in Russian] ties of Ukrainian confessional life. Bulletin of the Yanka Kupala State Uni-

7. Lossky, N. Synodality-catholicity and Primacy in Orthodox ecclesiRussian]

8. Lototsky, O. G. Autocephaly. Essay on the history of autocephaly. P. 207 [in Ukrainian].

9. Nicholas of Serbia, saint archbishop. The faith of the saints. Catechism of the Eastern Orthodox Church. Moscow: publishing house Nikeya,

Russian]. 2020 sociology). Retrieved from: http://razumkov.org.ua/napriamky/ sotsiologichni-doslidzhennia/otsinka-gromadianamy-diialnosti-vlady-rivenPor [in Ukrainian]. № 157 from 25-26 December 2013. Retrieved from: http://www.patriarchia.ru/ $\mathrm{db} / \mathrm{text} / 3481089 . \mathrm{html}$ [in Russian].

12. Rules of the Orthodox Church with the interpretations of Nicode(Reprinting: Reprint: Edition of the Holy Trinity Sergius Lavra, 1996). Volume 2. P. 649 [in Russian].

13. Rules of the Holy Local Councils with interpretations. In 2 parts. part. Rules of the first six Holy Local Councils. - St. Petersburg, 2001. news/pravoslavnaja-cerkov-i-protesty-v-belorussii-3.duUруАек. [in Russian].

15. Sagan, O. Universal Orthodoxy: nature, history, current status.

16. Kyiv: Dukh i Litera, 2020, p. 220 [in Ukrainian].

17. Tsypin, V., archpriest. Canon law. Moscow: Publishing house of 9. 864 [in Russian]

(he prism of №3. Pp. 197-224 [in Russian].

19. Sokolovsky, O. L. Christological discourse in the period of the Fifth Ecumenical Council. Gileya. Kyiv, 2018. Issue 135 (№ 8). Pp. 170-175 [in Ukrainian].

Надійшла до редколегії 02.08.20
1. Bolotov, V. Lectures on the history of the ancient church (in 4 volScience. № 1 (166). Grodno, 2014. Pp. 120-126 [in Russian].

Archimandrite Kirill Govorun. 08.16.2020. Retrieved from: https://reltoday.com/ 
А. Р. Кобетяк

Житомирский государственный университет имени Ивана Франко, Житомир, Украина

\title{
ЭККЛЕЗИОЛОГИЧЕСКАЯ ОБУСЛОВЛЕННОСТЬ АВТОКЕФАЛЬНОГО УСТРОЙСТВА
} ВСЕЛЕНСКОГО ПРАВОСЛАВИЯ

Рассматривается одна из фундаментальных проблем целого корпуса церковного права - автокефальный принцип существования церкви. Эта проблема углубляет исследовательское внимание к сущности существования православия в целом. Кроме теоретического обоснования, внутренний церковный строй имеет и практическое значение для процесса автокефализации новых национальных Поместных церквей. Это актуально в связи с борьбой ряда современных стран за церковную независимость и Вселенское признание. Государственная власть, начиная со времен Византийской империи, постоянно навязывала свой принцип и методы управления церковью, что часто шло вопреки традициям и каноническим нормам. Православная экклесиология предлагает собственный подход иерковно-административного управления. Доказано, что только автокефальный строй является единственным вариантом существования Вселенского православия.

Ключевые слова: автокефалия, экклесиология, церковь, православие, митрополия, кафедра, административное устройство.

удк $2-42$

DOI:10.17721/sophia.2020.15.4

І. В. Кондратьєва, д-р філос. наук, доц. Київський національний університет імені Тараса Шевченка, Київ, Україна ORCID: 0000-0003-3571-1681 e-mail: iryna.k@i.ua

\section{РЕЛІГІЙНІ ЦІННОСТІ ТА ПРАВА ЛЮДИНИ: ОСОБЛИВОСТІ КОРЕЛЯЦІї}

\begin{abstract}
Розглянуто особливості розуміння природи і сутності прав людини в рамках різних релігій, специфіку взаємозв'язку традиційних релігійних цінностей і людських прав у контексті сучасних реалій; проаналізовано особливості реліеійних концепцій прав людини (на прикладі світових реліеій) у їх взаємозв'язку та кореляцією з підходами до проблематики людських прав, що спираються значною мірою на ліберальне підґрунтя і знаходять своє відображення у відповідних міжнародних документах та рішеннях авторитетних міжнародних інституцій.
\end{abstract}

Ключові слова: релігія, релігійні цінності, права людини, глобалізація, релігійні права, релігійна свобода.

Дискурс прав людини відіграє важливу роль у сучасному світі, коли різноманітні міжнародні організації та інститути звертаються до проблематики людських прав і прагнуть відшукати шляхи "для імплементації фундаментальних прав людини в світі" [8, р. 2]. У світі, який є розмаїтим у своїх світоглядних, соціокультурних, ціннісних та інших вимірах. Зокрема, постає питання про духовне підґрунтя прав людської особистості, про роль релігії у формуванні універсальної системи прав людини та забезпеченні їх збереження й захисту. Ті, хто наголошує на необхідності релігії для визначення прав людини, безумовно мають відповідні підстави. Для них моральні істини не можуть бути ідентиффіковані без божественного одкровення, настанов божих та його керівництва. Слід визнати, що релігія єднає людей у спільноти, пропонує систему норм та ціннісних орієнтирів, стає вагомим моральним підґрунтям прав людини. Загалом, на думку А. Садаката, релігію можна розглядати як своєрідний "каталізатор для прав людини" [8, p. 10]. Водночас досить поширеною в сучасному світі стає секулярний погляд, згідно з яким існуючі теорії прав людини та практики їх забезпечення мають суто світську, а не релігійну основу.

Стаття має на меті аналіз особливостей бачення природи і сутності прав людини в релігійних віруваннях, специфіки взаємозв'язку традиційних релігійних цінностей і людських прав у контексті реалій сьогодення.

Проблема суперечливого взаємозв'язку релігійних уявлень, норм і цінностей та прав людини в контексті сучасних реалій перебуває на перетині дослідницьких зацікавлень представників різних сфер релігієзнавчогуманітарного та правового знання. ІЇ̈ розмаїті аспекти знаходять своє висвітлення у працях як вітчизняних, так і зарубіжних авторів, насамперед, В. Єленського, С. Ладивірової, М. Черенкова, Ю. Чорноморця, П. Яроцького, Л. Сюкіяйнена, Ф.М.Шеферда, Б. Барнетта, У. М. Бока, М. 3. Хана, М. Дж. Бройді, Дж. В. Бройді, Р. Траера, М. А. Бадеріна, Х. Бадзе,
3. Сванк, 3. 3. Кало, П. Дж. Кароззи, Д. Філпотта, Е. Клапсіса, Л. А. Корсері, П. Ганеа, А. Стефенса, Р. Валдена, Дж. Доннеллі, А. Ферона та ін.

Слід визнати, що базові цінності провідних релігійних традицій світу відіграли помітну роль у формуванні своєрідної універсальної системи людських прав. 3 іншого боку, релігії світу приділяють велику увагу виробленню власних концепцій прав людини, які відповідним чином корелюють із сучасними ліберальними теоріями людських прав. За великим рахунком, сьогодні в різних частинах світу "як релігія, так і права людини утворюють паралельні форми соціального порядку, які обов'язково повинні взаємодіяти між собою" [5, р. 83].

Релігійні вчення в цьому контексті розрізняються між собою за деякими важливими аспектами, вихідні засади існуючих релігій часто не збігаються між собою через низку принципових моментів. Серед них, зокрема, питання щодо ролі, яку відіграють релігійні традиції в правовому розвитку окремих країн і регіонів. До того ж слід зазначити, що співвідношення релігійних вірувань і прав людини в Європі завжди носило динамічний характер, зазнавало відповідних, часом досить суттєвих трансформацій. Ця еволюція була пов'язана, зокрема, з формуванням концепції прав людини в ії ліберальному варіанті. I, слід визнати, що в цьому процесі помітну роль відіграли традиційні релігійні уявлення і цінності. Так, не викликає сумніву той факт, що значною мірою "політичні й ліберальні теорії спираються на концепції індивідуальної свободи та автономії" [8, р. 78], що знайшли своє обґрунтування в рамках християнської традиції.

Слід визнати, що релігійні уявлення про права людини, спроби їх концептуального оформлення далеко не завжди і не в усьому узгоджувались із вихідними положеннями світських концепцій людських прав. Зокрема, це стосується витоків цих прав, які, наприклад, ліберальна думка Європи зазвичай пов'язувала з природою людської особистості, з ії̈ вродженими невід'ємними правами, а релігійні вчення вбачали в божествен- 